\title{
Morphobiomechanical changes in quadriceps femoris muscle of schoolchildren during isometric and isokinetic exercises
}

\author{
G. Knipshe ${ }^{1}$ \\ L. Cupriks ${ }^{2}$
}

https://doi.org/10.5628/rpcd.03.03.64

\author{
${ }^{1}$ Department of Anatomy, Physiology and Biochemistry \\ Latvian Academy of Sport Education \\ ${ }^{2}$ Department of Weightlifting, \\ Latvian Academy of Sport Education
}

\begin{abstract}
Success in any kind of sport is determined by a definitive relation of such physical qualities as strength, speed, endurance, ability and coordination (1). In most kind of sports the most important is not absolute strength but its distribution in time period. Therefore, evaluation of level of speed and strength ability and its further development is very important in selecting children for sport $(2,3)$. Thirty five 8-10 years old schoolchildren of both gender took part in our research. By the help of the dynamometric device REV 9000 made by the company "Technogym" we monitored changes in strength of quadriceps femoris in a time period, which allowed to evaluate visually the process of muscle contraction and relaxation, as well as the importance of strength and changes in its speed in a time period. The statistic analysis of the data showed great differences of maximal strength and relaxation speed. The comparison of contracting and relaxation in the obtained curves allowed us to distinguish different variants of muscle contracting and relaxing relation. We found the following variants of the relationship of muscle contraction and relaxation: (i) children with very fast muscle contraction and very fast relaxation; (ii) children with fast muscle contraction and fast relaxation; (iii) children with fast muscle contraction but slowly relaxation; (iv) children with slowly muscle contraction but fast relaxation; and $(v)$ children with slowly muscle contraction and slowly relaxation.
\end{abstract}

Key Words: muscle strength, isometric, isokinetic, children.

\section{RESUMO}

Alterações morfológicas e biomecânicas no músculo quadriceps femoris em crianças de idade escolar durante a execução de exercícios isométricos e isocinéticos.

O sucesso no desporto é determinado de forma decisiva por capacidades motoras como a força, a velocidade, a resistência e a coordenação (1). Na maior parte dos desportos o mais importante não é a força absoluta mas a sua utilização no tempo. Por isso, a avaliação do nível das capacidades de velocidade e de força e o seu posterior desenvolvimento é muito importante quando se procura recrutar crianças para o desporto $(2,3)$. Trinta e cinco crianças em idade escolar de ambos os sexos, com idades compreendidas entre os 8 e os 10 anos, participaram no nosso estudo. As alterações nos desempenhos de força do quadriceps femoris foram monitorizadas com a ajuda do dinamómetro REV 9000, da "Technogym" o que permitiu avaliar, visualmente, o processo de contração e relaxação muscular, bem como a importância da força e das alterações na velocidade de desempenho em períodos de tempo determinados. A análise estatística dos resultados mostrou grandes diferenças na força máxima e na velocidade de relaxação. A comparação das curvas de contracção e de relaxação permitiu-nos distinguir diferentes variantes na relação entre a relaxação e a contracção musculares: (i) crianças com contracção e relaxação musculares muito rápidas; (ii) crianças com contracção e relaxação musculares rápidas; (iii) crianças com contracção muscular rápida, mas com relaxação lenta; (iv) crianças com contracção muscular lenta, mas com relaxação rápida; $e$ (v) crianças com contracção e relaxação musculares lentas.

Palavras-chave: força muscular, exercícios isométricos, exercícios isocinéticos, crianças. 


\section{INTRODUCTION}

An objective evaluation of children physical condition is a difficult task, especially if we need to select children for different kinds of sport or involve them in sports training and competitions. It is the simplest way to focus only on the competition result, however, as experience shows, it is not a sufficiently safe way. One of the most difficult questions in selection is the choice of the selection competition time. Too early participation in the competitions may not be according to an individual's physical condition level, it requires a great consumption of his strength and energy, and not everybody can restore it.

The evaluation of an individual's physical condition is also very important during the study-training process, providing a rational choice of loads and an operative correction making.

To solve such a difficult problem as safe physical condition criteria evaluation or in the biological meaning - stating of a body adaptation abilities, a complex approach is needed that would take into account peculiarities of different organ functions and their adaptation abilities to physical loads.

One of the main principles of the adoptive behaviour is maximal work at maximal use of energy and a full structurally - functional restoration $(4,5)$.

Thus, putting emphasis only on the physical condition, we can evaluate only one of the adaptive abilities - the maximal work effect. At the same time such important adaptive abilities as the level of energy usage, the economy of biosystem functions and structurally - functional restoration remain unestimated. The above mentioned leads us to a great number of mistakes in athlete selection.
Success in any kind of sport is determined by a definitive relation of such physical qualities as strength, speed, endurance, ability and coordination (1). In most kinds of sport the most important is not absolute strength but its distribution in time period. Therefore evaluation of level of speed and strength ability and its further development is very important in selecting children for sport $(2,3)$.

\section{METHODS}

Thirty five 8 to 10 years old schoolchildren of both gender took part in our research. By the help of the dynamometric device REV 9000 made by the company "Technogym" we monitored the changes in strength of quadriceps femoris in a time period, which allowed to evaluate visually the process of muscle contraction and relaxation, as well as the importance of strength and changes in its speed in a time period. During the measuring the pupils were in the sitting position. Knee joint was flexed at $85^{\circ}$ angle and fixed with the help of a special device. To avoid movements in other joints, chest and hips were fixed with stabilising belts. The task was given to the pupils: to tense and then to relax muscles as fast as possible. The isokinetic analysis consisted of three repetitions at speed 70,100 , and $150^{\circ}$ s. Before the test and during it passive flexion and extension movements in knee joint with the speed of $120^{\circ} / 90$ s between different angular movement speed were executed.

\section{RESULTS}

The result analysis shows slight differences in the parameters of maximal strength, work and power for both: flexors and extensors at different speed (Table 1).

\begin{tabular}{|c|c|c|c|c|c|c|c|c|c|c|c|c|}
\hline & \multicolumn{4}{|c|}{$70 \%$} & \multicolumn{4}{|c|}{$100 \% \mathrm{~s}$} & \multicolumn{4}{|c|}{$150 \% \mathrm{~s}$} \\
\hline & \multicolumn{2}{|c|}{ ext } & \multicolumn{2}{|c|}{ flex } & \multicolumn{2}{|c|}{ ext } & \multicolumn{2}{|c|}{ flex } & \multicolumn{2}{|c|}{ ext } & \multicolumn{2}{|c|}{ flex } \\
\hline & $\mathrm{R}$ & $\mathrm{L}$ & $\mathrm{R}$ & $\mathrm{L}$ & $\mathrm{R}$ & $\mathrm{L}$ & $\mathrm{R}$ & $\mathrm{L}$ & $\mathrm{R}$ & $\mathrm{L}$ & $\mathrm{R}$ & $\mathrm{L}$ \\
\hline maximal & 70 & 63 & 55 & 50 & 59 & 49 & 45 & 38 & 43 & 33 & 39 & 31 \\
\hline strength & \pm 12 & \pm 15 & \pm 11 & \pm 12 & \pm 11 & \pm 12 & \pm 7 & \pm 10 & \pm 10 & \pm 8 & \pm 10 & \pm 8 \\
\hline \multirow[t]{2}{*}{ total work } & 90 & 77 & 69 & 63 & 70 & 63 & 61 & 50 & 63 & 54 & 49 & 39 \\
\hline & \pm 32 & \pm 15 & \pm 13 & \pm 18 & \pm 13 & \pm 15 & \pm 15 & \pm 13 & \pm 15 & \pm 12 & \pm 11 & \pm 13 \\
\hline \multirow[t]{2}{*}{ power } & 42 & 40 & 41 & 40 & 81 & 72 & 77 & 60 & 100 & 87 & 88 & 72 \\
\hline & \pm 12 & \pm 8 & \pm 9 & \pm 9 & \pm 21 & \pm 26 & \pm 15 & \pm 20 & \pm 21 & \pm 19 & \pm 18 & \pm 20 \\
\hline
\end{tabular}

Table 1: Isokinetic analysis of right $[R]$ and left $[L]$ knee extensors and flexors at speed 70,100 and $150 \%$. 
The statistical analysis of the data showed a high maximal strength and relaxation speed variety. The variety coefficient of strength parameters for different muscle groups was $15-20 \%$, rapid force indices 25 $30 \%$, but for the relaxation speed $40-45 \%$. The comparison of contracting and relaxation in the obtained curves allowed us to distinguish different variants of muscle contracting and relaxing relation, according to inter-correlation analysis between test results, body mass, length and contractility and relaxing of the skeletal muscles of schoolchildren (Table 2).

Table 2: Inter-correlation analysis between test results, body mass, length, and contractility and relaxing of the skeletal muscles of schoolchildren ( $n=35, r=0,400, p<0,05$ ).

\begin{tabular}{|l|l|l|l|l|l|l|l|l|l|l|l|l|l|l|l|l|}
\hline & 1 & 2 & 3 & 4 & 5 & 6 & $?$ & 8 & 9 & 10 & 11 & 12 & 13 & 14 & 15 & 16 \\
\hline 1 & - & -082 & 041 & 082 & 198 & 225 & 199 & -062 & 170 & 140 & 257 & 418 & 405 & 1747 & -07 & 501 \\
2 & - & 662 & 428 & -257 & -209 & -099 & 175 & 081 & -033 & -216 & 020 & -124 & 042 & 120 & -167 \\
3 & & - & 944 & -032 & -037 & -119 & 122 & 1056 & -076 & -309 & 158 & -056 & 465 & 071 & -231 \\
4 & & & - & 043 & 033 & -093 & 083 & 060 & -110 & -318 & 121 & -078 & 450 & 069 & -213 \\
5 & & & & - & 948 & 635 & -035 & -303 & -310 & 253 & 064 & 076 & 314 & 251 & 168 \\
6 & & & & & - & 784 & -119 & -264 & -271 & 197 & 009 & 022 & 245 & 318 & 058 \\
7 & & & & & & - & -212 & -124 & -113 & 090 & -098 & -070 & 023 & 254 & -118 \\
8 & & & & & & & - & -463 & -478 & 001 & -055 & -073 & 212 & -094 & 273 \\
9 & & & & & & & & - & 979 & -001 & 529 & 502 & -151 & -359 & -158 \\
10 & & & & & & & & & - & 046 & 494 & 510 & -253 & -378 & -119 \\
11 & & & & & & & & & & - & 159 & 222 & -080 & 066 & 318 \\
12 & & & & & & & & & & & - & 971 & 067 & -542 & 184 \\
13 & & & & & & & & & & & & - & -042 & -581 & 247 \\
14 & & & & & & & & & & & & & - & 232 & 171 \\
15 & & & & & & & & & & & & & & - & -066 \\
16 & & & & & & & & & & & & & & & - \\
\hline
\end{tabular}

We found the following variants of the relationship of muscle contraction and relaxation:

- children with very fast muscle contraction and very fast relaxation,

- children with fast muscle contraction and fast relaxation,

- children with fast muscle contraction but slowly relaxation,

- children with slowly muscle contraction but fast relaxation,

- children with slowly muscle contraction and slowly relaxation.

\section{DISCUSSION}

Having compared the developed maximal strength moments of knee joint extensors in the dominant (right) and not dominant (left) leg, they do not differ significantly $(p>0,05)$, but the difference between the quantities has a tendency to increase at the increase of the angular speed. The relaxation between the flexor/extensor strength moments of the dominant and not dominant leg does not differ significantly.

Having carried out the children post-experiment testing applying the jump method, we stated that after 5 and 10 jumps the children did not have only a different result, but also a different execution time. It is due to uneven abilities to adapt from tension to relaxation and again to tension. The decrease of the children results is possible to explain by an active growth of lower extremities at this age (2).

According to the results obtained by us, the relations of children knee extensor/flexor strength movements in the middle part of the joint movement amplitude are close to $85 \%$. It means that strength of both muscle groups increases proportionally.

Este artigo foi apresentado durante o $22^{\text {nd }}$ Pediatric Work Physiology Meeting e deveria ter sido publicado no número especial da Revista Portuguesa de Ciências do Desporto dedicado às actas do congresso.

\section{CORRESPONDÊNCIA}

\section{Gundega Knipshe}

Department of Anatomy, Physiology and Biochemistry Latvian Academy of Sport Education anatomy@lspa.lanet.lv

\section{REFERENCES}

1 Visochin, J. (1987). Scientific Papers Leningrad Univ.. Leningrad, 5-18 (in Russian).

2 Aboltina, M.; Knipse, G.; Umbrasko, S. (1995). Scientific Papers LASE. Riga, 180-190 (in Latvian).

3 Verhoshansky, Y.; Lazarev, V. (1989). Training in Sports. NSCAI, 11 (2): 56-61 (in Russian).

4 Visochin, J.V. (1983). Strategy of sportsmen neuromuscular apparat long-time adaptation to load. Works: $\mathrm{L}$.

5 Knapik J.; Wright, J. E.; Mawdsley, R.H.; J. Braun (1983). Isometric, isotonic, and isocinetic torque variations in four groups through a range of joint motion. J. Am. Phys. Ther. Assoc. 63(6): 938-947. 